\title{
Mineralogical characterization of clay fraction of Chalan Beel soils of Bangladesh
}

\author{
A.B.M.S. Islam ${ }^{1}$ and M.S. Hussain ${ }^{2}$ \\ ${ }^{1}$ Department of Soil Science, Patuakhali Science and Technology University, Dumki, Patuakhali-8602 \\ ${ }^{2}$ Department of Soil, Water and Environment, University of Dhaka, Dhaka-1000
}

\begin{abstract}
Top soils of four different series viz Jaonia (Typic Haplaquept), Halti (Typic Haplaquept), Taras (Aeric Haplaquept) and Digli (Typic Haplaquept) developed on Atrai river alluvium were studied to investigate the clay mineralogical composition. X-ray diffraction technique was employed to identify and quantify the minerals. The XRD patterns were obtained with Ni-filter $\mathrm{Cu} k \alpha$ - radiation at a scanning speed of $2^{\circ} 2 \theta \mathrm{min}$ and the amount of minerals was estimated by XRD peak intensities at parallel powder mount. Mica was the dominant clay mineral $(33-51 \%)$ in all soils, followed by quartz (13-19\%). The kaolinite contents were small $(8-10 \%)$ over the soils. The occurrence of vermiculite in the Digli and Taras soils (9 and $7 \%$ respectively) indicates a considerable transformation of mica. There is very little or no smectite minerals in the soils which might be due to poor parent material and disappearance of smectite from the top soils. Appreciable amount of primary minerals like quartz and feldspars have also been observed in the clay fraction of the soils.
\end{abstract}

Keywords: Clay minerals, Chalan beel, X-ray diffraction

\section{Introduction}

Chalan Beel, the largest beel in Bangladesh, is the low lying wetland area between the Barind tract and the Ganges river floodplains (Uddin, 2002). The Chalan beel area belongs to the physiographic unit, Lower Atrai Basin (FAO-UNDP,1988). Chalan beel is one of the large inland depressions of marshy land and is also one of the richest wetlands in the northern parts of Bangladesh.

It is located between $24^{\circ} 05^{\prime}$ to $24^{\circ} 35^{\prime}$ north latitude and $89^{\circ}$ to $89^{\circ} 35^{\prime}$ east longitude. The beel extends over the adjacent districts of Rajshahi, Pabna, Sirajgonj, Natore and Naogaon. It comprises a series of depressions inter-connected by various channels to form more or less one continuous cover of water in the rainy season when it covers an area of about $368 \mathrm{sq}$. km. (36,800 ha). A survey carried out in 1909 by the Public Works Department (PWD) about the drainage and silting up of the beel found that the original area of the beel which was about 1,088 sq. km.(108,800 ha) has been reduced to about 368 sq. km (36,800 ha).

The clay fraction, which contains mineral materials, has great influence on the development of soil physical and physico-chemical properties. The mineral part of the clay fraction consists of layer aiuminosilicates, oxides and hydroxides of iron, aiuminum and manganese. In most soil, properties of water retention, hydraulic conductvity, sewelling and shrinking and cation exchange are largely controlled by mineralogical composition. Identification and characterization of clay minerals are one of the basic requirements for classifying soils as well as for better understanding of soil genesis. Agronomic practices to great extent depend on mineralogical properties of clay in soil for which soil belong to its inherent fertility status. The abundance of specific silicate minerals indicates the weathering stage of soils. The high kaolinite content is consistent with the weathering condition experienced by soil in the humid tropics (Dixon, 1977). Under high temperature, humidity and leaching conditions, most common primary minerals such as mica and feldspars weather directly to kaolinite (Nwadialo and Lietzke, 1989). When soils are intensively cropped in high yielding environment, fixation 
and release of nutrient elements mainly govern crop response to indigenous and applied plant nutrients (Olk et al., 1995). Therefore, understanding the mechanism responsible for ion exchange, fixations etc. are vital for developing soil fertility management strategies to maximize the efficiency of nutrient uptake from soil and fertilizers.

Bangladesh has a wide range of soils developed in parent materials ranging from recent alluvial deposits to sedimentary rocks of tertiary formation (Saheed and Hussain, 1992). Under the influence of varied topographical condition and subsequent drainage patterns, the mineralogical composition of soils is also varied widely. A comprehensive study on mineralogical properties of soils developed under different parent materials not only provide information for family level classification but also indispensable for assessment of its inherent potentiality and better management practices. "Atrai river alluvium" is the parent material which covers an area of around 98,000 ha area of Bangladesh (Hussain,1992). These noncalcareous floodplain soils are very important from agricultural point of view.

The properties of soils of an area vary greatly with the content and properties of clay minerals. Moreover, the availability of soil nutrients depends significantly on clay minerals persist in the respective soils of the concerned area. From this point of view, determination of clay minerals along with their quantification in the soils of Chalan Beel were investigated for detailed characterization.

\section{Materials and Methods}

\section{Study area}

The soil samples were collected from the Chalan Beel area of Bangladesh between $24^{0} 05^{\prime}$ to $24^{\circ} 35^{\prime}$ north latitude and $89^{\circ}$ to $89^{\circ} 35^{\prime}$ east longitude located in singra Upazila of Natore district. For reference, GPS (Geographical Positioning System) readings with locations are mentioned in Table 1.

Table 1. Soil series, location and GPS readings of soil sampling.

\begin{tabular}{|c|c|c|c|c|c|c|c|c|}
\hline \multirow{2}{*}{$\begin{array}{l}\text { Soil } \\
\text { Series }\end{array}$} & \multirow{2}{*}{$\begin{array}{l}\text { Duration } \\
\text { of } \\
\text { inundation }\end{array}$} & \multirow[t]{2}{*}{$\mathrm{AEZ}(\mathrm{s})$} & \multicolumn{4}{|c|}{ Location } & \multirow{2}{*}{$\begin{array}{l}\text { Latitude and } \\
\text { longitude }\end{array}$} & \multirow{2}{*}{$\begin{array}{c}\text { Area* } \\
\text { (ha) }\end{array}$} \\
\hline & & & Village & Union & Upazila & District & & \\
\hline Jaonia & 4-5 Months & $\begin{array}{l}\text { Lower Atrai } \\
\text { Basin }\end{array}$ & Parshawile & Kalam & Singra & Natore & $\begin{array}{l}24^{\circ} 29^{\prime} 049^{\prime \prime} \mathrm{N} \\
89^{\circ} 09^{\prime} 495^{\prime \prime} \mathrm{E}\end{array}$ & 16,228 \\
\hline Halti & 5-6 Months & $\begin{array}{l}\text { Lower Atrai } \\
\text { Basin }\end{array}$ & Hizoli & Italy & Singra & Natore & $\begin{array}{l}24^{\circ} 28^{\prime} 464^{\prime \prime} \mathrm{N} \\
89^{\circ} 12^{\prime} 088^{\prime \prime} \mathrm{E}\end{array}$ & 14,406 \\
\hline Taras & 5-6 Months & $\begin{array}{l}\text { Lower Atrai } \\
\text { Basin }\end{array}$ & Chaugram & Chaugram & Singra & Natore & $\begin{array}{l}24^{\circ} 32^{\prime} 039^{\prime \prime} \mathrm{N} \\
89^{\circ} 10^{\prime} 659^{\prime \prime} \mathrm{E}\end{array}$ & 44,678 \\
\hline Digli & 4-5 Months & $\begin{array}{l}\text { Lower Atrai } \\
\text { Basin }\end{array}$ & Rakhalgasa & Singra & Singra & Natore & $\begin{array}{l}24^{\circ} 31^{\prime} 514^{\prime \prime} \mathrm{N} \\
89^{\circ} 08^{\prime} 730^{\prime \prime} \mathrm{E}\end{array}$ & 17,821 \\
\hline & & & & & & & Total & 93,133 \\
\hline
\end{tabular}

*Source: Hussain et al.,(2003)

\section{Soils}

Four soil series from different locations of Lower Atrai Basin were selected for the study. GPS was used to locate the position of the sites from where top soil samples (Ap1) were collected. Basic information of those four soil series are given in the Table 2. 
Table 2. Information regarding some properties of the soils studied.

\begin{tabular}{|c|c|c|c|c|c|c|c|c|c|c|c|}
\hline \multirow[t]{2}{*}{ Soil Series } & \multirow[t]{2}{*}{ Horizon } & \multirow[t]{2}{*}{$\begin{array}{l}\text { Depth } \\
(\mathrm{cm})\end{array}$} & \multirow[t]{2}{*}{$\mathrm{pH}$} & \multicolumn{3}{|c|}{$\begin{array}{c}\text { Particle Size } \\
\text { Distribution (\%) }\end{array}$} & \multirow[t]{2}{*}{ Texture } & \multirow[t]{2}{*}{$\begin{array}{c}\text { Sand/Silt } \\
\text { ratio }\end{array}$} & \multirow{2}{*}{$\begin{array}{l}\text { Silt/ } \\
\text { Clay } \\
\text { ratio }\end{array}$} & \multirow[t]{2}{*}{$\begin{array}{l}\text { Bulk } \\
\text { density }\end{array}$} & \multirow[t]{2}{*}{$\begin{array}{l}\mathrm{HM}^{*} \\
(\%)\end{array}$} \\
\hline & & & & Sand & Silt & Clay & & & & & \\
\hline Jaonia & Ap1 & $0-10$ & 6.8 & 2 & 46 & 52 & Silty clay & 0.04 & 0.88 & 1.55 & 2.10 \\
\hline Halti & Ap1 & $0-13$ & 6.2 & 1 & 41 & 58 & Silty clay & 0.02 & 0.71 & 1.54 & 4.19 \\
\hline Taras & Ap1 & $0-12$ & 6.2 & 0 & 31 & 69 & clay & 0.0 & 0.45 & 1.40 & 4.28 \\
\hline Digli & Ap1 & $0-9$ & 6.4 & 4 & 28 & 68 & clay & 0.14 & 0.41 & 1.22 & 3.05 \\
\hline
\end{tabular}

${ }^{*} \mathrm{HM}=$ Hygroscopic moisture

\section{Separation of clay fraction}

$10 \mathrm{~g}$ of air dry soil was treated with $30 \% \mathrm{H}_{2} \mathrm{O}_{2}$ heated for about $2 \mathrm{~h}$ to decompose organic matter. Excess $\mathrm{H}_{2} \mathrm{O}_{2}$ was removed by centrifugation by washing 3 times with water and $3 \mathrm{~m}$ $\mathrm{Nacl}$ was added each time to prevent defluculation of clay particles and the supernatant was discarded by decantation. The $\mathrm{pH}$ of the soil suspension was adjusted to 10 by addition of $1 \mathrm{~N}$ $\mathrm{NaOH}$. Clay fraction $(<2 \mu \mathrm{m})$ was separated by repeated sedimentation-siphoning method (Moslehuddin et al., 1998)

\section{Mineralogical analysis}

Identification and estimation of mineralogical composition were carried out by $\mathrm{X}$-ray diffraction (XRD). The separated clay fraction was treated by $1 \mathrm{M} \mathrm{KCl}$ and $0.5 \mathrm{~N} \mathrm{MgCl}_{2}$ respectively to make $\mathrm{K}^{+}$and $\mathrm{Mg}^{+}$saturated clay and washed them with ethanol to remove excess salts. An amount of $0.4 \mathrm{ml}$ solution was dropped on a glass slide covering two third of its area, air dried, and X-rayed (parallel powder mount). In addition to the air-dry specimen, the Mgsaturated clay was X-rayed after saturation with glycerol; and $\mathrm{K}$ - saturated clay after heating at $300^{\circ} \mathrm{C}$ and $550^{\circ} \mathrm{C}$ for two hours. The XRD patterns were obtained using Shimarzu XRD6000 diffractometer with Ni-filtered $\mathrm{Cu}$ k $\alpha$ - radiation at $40 \mathrm{kV}$ and $30 \mathrm{~mA}$ at a scanning speed of $2.0^{\circ} / \mathrm{min}$ over a range of $3-35^{\circ} 2 \theta$. Approximate mineral contents of clay fraction were estimated on the basis of the relative peak intensities in the XRD patterns as described by Islam and Lotse (1986). The intensities ratio of two components $P$ and $Q$ in a multicomponent mixture can be related to their weight ratio as follows:

$$
\mathrm{Ip} / \mathrm{lq}=\mathrm{Kp} . \mathrm{q} \mathrm{Wp} / \mathrm{Wq}
$$

Where Ip and Iq are the intensities of the $P$ and $Q$ components in XRD, Wp and $W q$ are the weight proportion of $P$ and $Q$ components and Kp.q a constant value, is the intensity-weight coefficient of $P$ and $Q$ components. Reflection of the Mg-saturated and glycerol solvent specimen were mainly used to calculate the amount of different minerals.

\section{Results and Discussion}

X-ray diffractograms of clay fraction of the four soil samples under the present investigation have been presented in Figures 1- 4. For the identification of minerals in the clay fraction it was assumed that the $17 \AA$ peak in the glycerol solvated samples was an indication of the presence of smectite mineral. The peak at $14 \AA$ which collapsed when heated to $550^{\circ} \mathrm{C}$ indicates the presence of vermiculite. The peak at $14 \AA$ which does not collapse on heating at $550^{\circ} \mathrm{C}$ is due to chlorite. The peak at $10 \AA$ in the glycerol solvated clay samples was caused by the presence of mica. The peak at $7.2 \AA$ dissappearing on heating the sample at $550^{\circ} \mathrm{C}$ confirmed the presence of kaolinite mineral. A number of small peaks in the region of $10 \AA$ to $14 \AA$, some of which persist on glycerol solvation of the clay, suggested the presence of 
interstratified minerals, most likely of the kaolinite, illite and vermiculite. Presence of quartz is indicated by the presence of $3.35 \AA$ peak. The relative amounts of various minerals in the clay fraction were estimated semi-quantitatively on the basis of peak areas in the X-ray diffractograms (Millot, 1964). Amounts of minerals determined by the above method are presented in Table 3 . In the present soils mica is the dominant clay mineral closely followed by quartz. A small quantity of kaolinite is present in all the soils. Small quantities of vermiculite and interstratified minerals are present in some specific soils. These results appear to be in conformity with the findings of White (1985) and Khan et al., (1997) for some soils of Bangladesh.

The soils under study contained $8-10 \%$ kaolinite (Table 3). Dixon (1977) noted that kaolinite is one of the widespread clay minerals in most soils indicating an incipient stage of weathering. Brady (1994), Jackson and Sherman (1953) stressed that kaolinite represents a more advanced stage of weathering than does any other major types of silicate clays and formed from the decomposition of silicates under conditions of moderate to strong acid weathering environment which results in the removal of the alkalies and alkaline earth metals. Gupta et al., (1984) makes an opinion that kaolinite usually forms under well drained condition through the weathering of feldspars. In the floodplain (Chalan beel) soils of Bangladesh the kaolinite mineral is thought to be allogenic in nature and are derived from parent material.

Table 3. Approximate mineral contents (\%) in the clay fraction of Chalan beel soils

\begin{tabular}{|l|c|c|c|c|c|c|c|c|c|}
\hline \multirow{2}{*}{$\begin{array}{l}\text { Soil } \\
\text { Series }\end{array}$} & \multicolumn{10}{|c|}{ \% Mineral content* } \\
\cline { 2 - 10 } & $\mathrm{Mc}^{* *}$ & $\mathrm{Vt}$ & $\mathrm{Kt}$ & $\mathrm{St}$ & $\mathrm{Ch}$ & $\mathrm{Vt}-\mathrm{Ch}$ & $\mathrm{Qr}$ & $\mathrm{Fd}$ & $\mathrm{Gb}$ \\
\hline Jaonia & 33 & - & 8 & - & 9 & 7 & 15 & - & - \\
\hline Halti & 37 & - & 7 & - & 7 & 11 & 14 & 16 & - \\
\hline Taras & 51 & 7 & 9 & - & - & 8 & 13 & - & 12 \\
\hline Digli & 37 & 9 & 10 & - & 5 & 5 & 19 & 13 & - \\
\hline Mean & 40 & - & 9 & - & - & 8 & 16 & - & - \\
\hline
\end{tabular}

${ }^{*}$ According to the method of Islam and Lotse (1986)

${ }^{* *} \mathbf{M c}=$ Mica, $\mathbf{V t}=$ Vermiculite, $\mathbf{K t}=$ Kaolinite, $\mathbf{S t}=$ Smectite (Montmorillonite), $\mathbf{C h}=$ Chlorite, $\mathbf{Q r}=$ Quartz, $\mathbf{F d}=$ Feldspar, $\mathbf{G b}=$ Gibbsite, $\mathbf{V t}-\mathbf{C h}=$ Vermiculite-Chlorite,

The present soils contain on an average 40 percent mica. Fanning and Keramidas (1977) pointed out that mica in most soils originate mainly from soil parent materials and tend to weather to other minerals with time. They generally are more prevalent in clay fraction of younger and less weathered soils (Entisols, Inceptisols, Alfisols).

The occurrence of 9 percent vermiculite in the present Digli soils indicates that the transformation of mica is considerable. Douglas (1977) stated that soil vermiculites are nearly always reported to occur as an alteration product of muscovite, biotite and chlorite. The transformation of mica to vermiculite during pedogenesis has been reported by Douglas (1977). The transformation sequence is: mica - vermiculite - hydroxyl - aluminum interlayered vermiculite. According to Douglas (1977) the transformation of micas to expandable 2:1 minerals may be represented by the following equation:

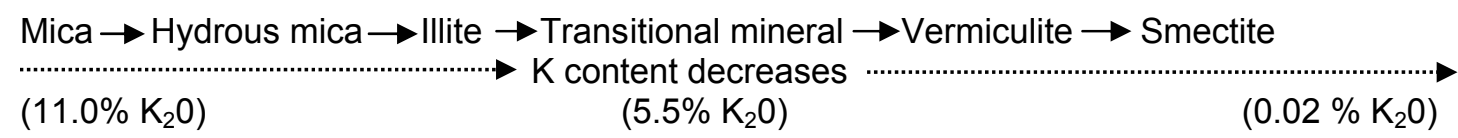


Since these soils have high content of mica mineral which is undergoing transformation to expandable minerals, easy replenishment of $\mathrm{K}$ in the soil solution may be expected. These soils therefore may not need potassic fertilizer application as the $K$ content in the soils was high. In such soils if any potassic fertilizer was applied then there was every possibility of reversing the reaction. The expanding lattice minerals after fixing $\mathrm{K}^{+}$in the inter lattice space may revert to illite. But the possibility of this kind of revertion might be remote in the seasonally flooded soils of Bangladesh as there was loss of nutrients in the draining water. Potassium in solution may be washed away by the draining water.

Since the soils are young it can be assumed that the minerals present in the studied soils were mainly inherited from their parent materials with little or no in situ post-depositional alteration. Ali (1994) noted that some in situ transformation might have taken place under the influence of local soil management practices. However, such change if any was small as the soils are in their incipient stage of development. From Table 3 it was observed that all the four studied soils contained moderate amount of quartz, the quantity of which ranged from 13-19 percent with a mean value of 16 percent; This result suggest that the soils are derived from parent materials containing fine grained quartz mineral in the clay fraction. Huizing (1971) and Hussain et al., (1989) studied the sand mineralogy of the major floodplain soils of Bangladesh and reported that Meghna floodplain contains relatively higher amount of Quartz. Finally, it can be stressed that an admixture of 9 percent kaolinite, 40 percent mica and 8 percent vermiculite-Chlorite occur in the clay fraction of the soils under the present study (Table 3). This may be considered as a bone as the soils with such mixed clay mineralogy will not show any extreme physical or physico-chemical property. Hussain and Swindale (1970) noted that in the poorly drained soils with high base status usually contain a clay mineralogy dominated by smectite. But in the Chalan beel soils there is very little smectite mineral. The reasons for the absence of smectite mineral in Chalan beel soils may be base poor parent material and acidic environment. With such a combination of clay mineralogical composition, the soils are expected to demonstrate a physical condition quite close to ideal for the agricultural management of the soils mainly for the production of rice crop. 


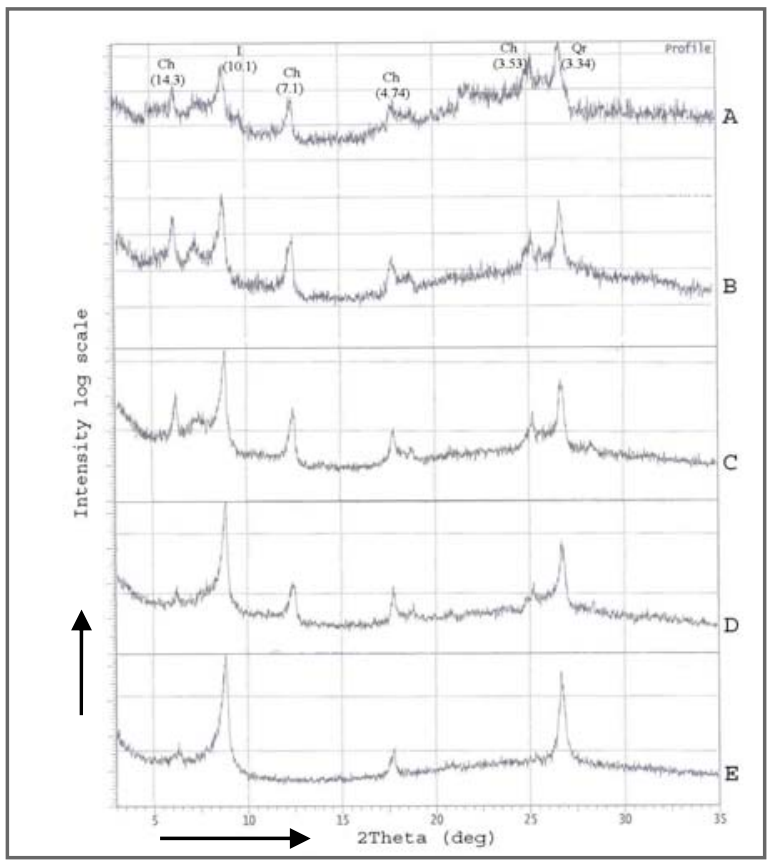

Fig 1. X-ray diffraction pattern of clay samples from surface horizon of Jaonia soil series. Treatments: A) Mg-saturation and glycerin treated; B) Mg-saturation and air-drying; C) K-saturation and air-drying; D) K-saturation and heating at $300^{\circ} \mathrm{C}$; E) K-saturation and heating at $550^{\circ} \mathrm{C}$.

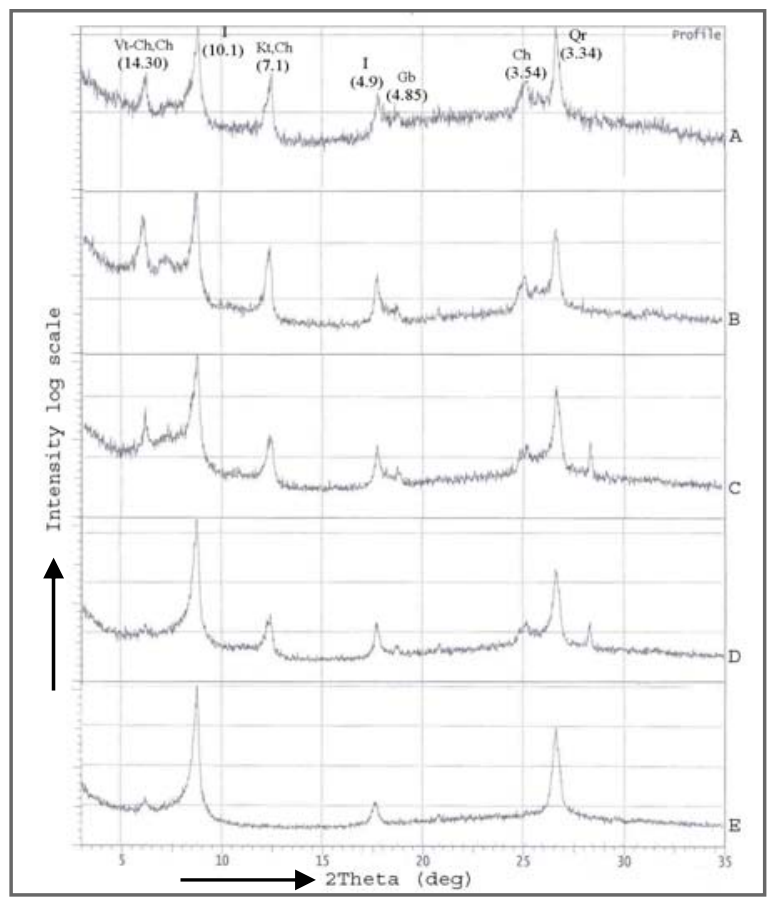

Fig 2. X-ray diffraction pattern of clay samples from surface horizon of Halti soil series.

Treatments: A) Mg-saturation and glycerin treated; B) Mg-saturation and air-drying; C) K-saturation and air-drying; D) K-saturation and heating at $300^{\circ} \mathrm{C}$; E) K-saturation and heating at $550^{\circ} \mathrm{C}$. 


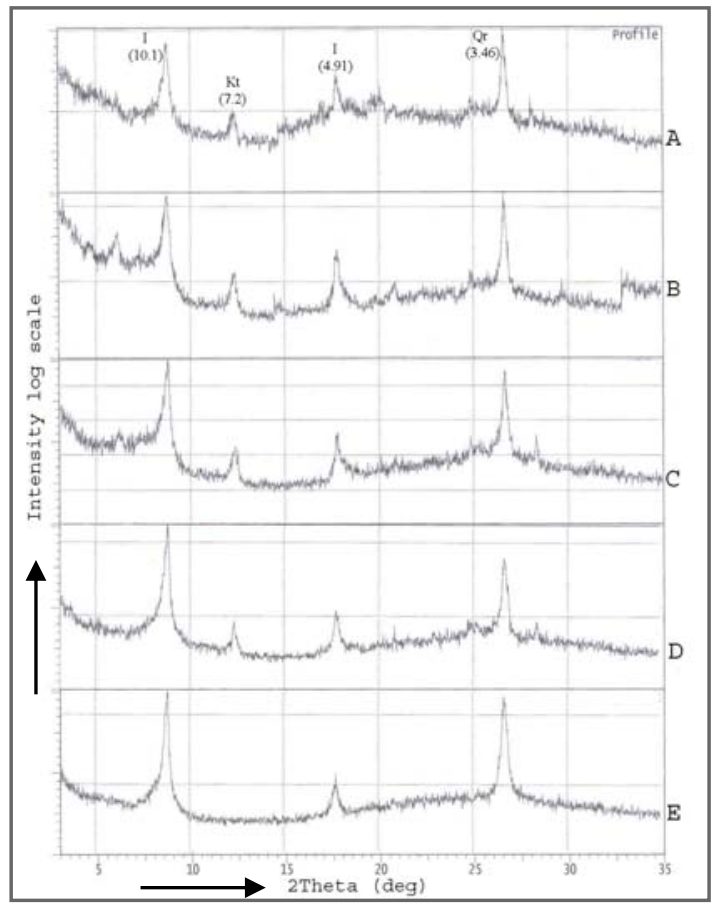

Fig 3. X-ray diffraction pattern of clay samples from surface horizon of Taras soil series.

Treatments: A) Mg-saturation and glycerin treated; B) Mg-saturation and air-drying; C) K-saturation and air-drying; D) K-saturation and heating at $300^{\circ} \mathrm{C}$; E) $\mathrm{K}$-saturation and heating at $550^{\circ} \mathrm{C}$.

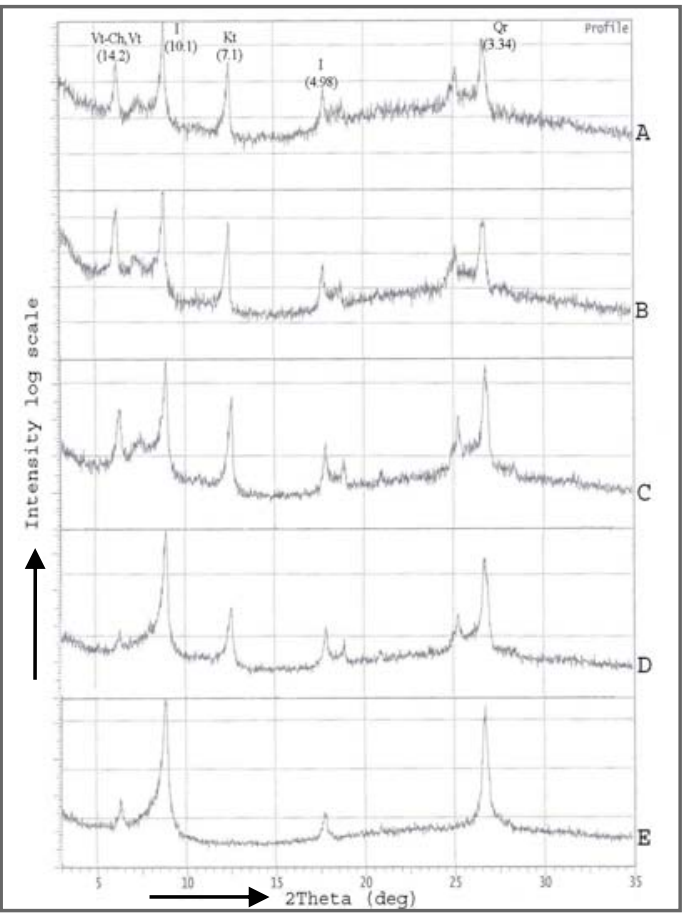

Fig 4. X-ray diffraction pattern of clay samples from surface horizon of Digli soil series.

Treatments: A) Mg-saturation and glycerin treated; B) Mg-saturation and air-drying; C) K-saturation and air-drying; D) K-saturation and heating at $300^{\circ} \mathrm{C}$; E) K-saturation and heating at $550^{\circ} \mathrm{C}$. 


\section{References}

Ali, M.F. 1994. Effects of alternate wetting and drying cycles on pedogenic processes of some representative Bangladesh soils. Ph.D. dissertation, University of Dhaka, Dhaka, Bangladesh.

Brady, N.C. 1994. The Nature and Properties of soils, $13^{\text {th }}$ Edition. MacMillan Publishers, London.

Dixon, J.B. 1977. Kaolinite and serpentine groups of minerals. In: Dixon, J.B. and S.B. Weed (Eds), Minerals in Soil Environments. PP. 357-403. Soil Science Society of America, Madison, Wisconsin, 795 p.

Douglas, L.A. 1977. Vermiculite. In : Dixon, J.B. and S.B. Weed (Eds.). Minerals in Soil Environments. PP. 259-292. Soil Science Society of America. Madison, Wisconsin, $795 \mathrm{p}$.

FAO - UNDP. 1988. Agroecological Region of Bangladesh, Report-2, FAO, Rome, 570p.

Fanning, D.S. and Keramidas, V.Z. 1977. Mica. In : Dixon, J.B and S.B Weed (Eds.) Minerals in Soil Environments. PP:195-258. Soil Science Society of America, Madison, Wisconsin, U.S.A. 795 p.

Gupta, R.D., Jha, K.K. and Sahi, B.P. 1984. Proc. Indian National Science Academy.51: 643 -649.

Huizing, H.G.J. 1971. A reconnaissance study of the mineralogy of sand fractions from East Pakistan sediments and soils. Geoderma. 6: 109-133.

Hussain, M.S. 1992. Soil classification with special reference to the soils of Bangladesh. University of Dhaka.

Hussain, M.S. and Swindale, L.D. 1970. A morphological and mineralogical study of the Grey Hydromorphic soils of the Hawaiian Islands. Pacific Sci. $24: 543-553$.

Hussain, M.S., Nahar, K., Islam, A.K.M.E. and Elahi, S.F. 1989. A morphological and clay mineralogical study of some soils from Bhola district in Bangladesh. Dhaka Univ. Stud. (Part-E) 4:93-104.

Islam, A.K.M.E. and Lotse, E.G. 1986. Quantitive mineralogical analysis of some Bangladesh soils with X-ray ion exchange and selection dissolution techniques, Clay Miner 21: 31-42.

Jackson, M.L. and Sherman, G.D. 1953. Chemical weathering of minerals in soils. Adv. Agron. 5: 221- 318.

Khan, Z.H., Mazumder, A.R., Hussain, M.S. and Saheed, S.M. 1997. Chemical and mineralogical properties of some Benchmark soils in the floodplains of Bangladesh. Journal of the Indian Society of Soil Science 45 (2) : 485-489.

Millot, G.1964. Geologic des Argiles. masson and Co. Paris 510p.

Moslehuddin, A.Z.M., Saheed, S.M. and Kazuhiko Egashira. 1998. Disappearing trends of smectite in Ganges floodplain soils of Bangladesh. Clay Sci. 10:349-362.

Olk, D.C., Cassaman, K.G. and Carlson, R.M. 1995. Kinetics of potassium fixation in vermiculite soils under different moisture regimes. Soil Sci.Soc.Am.J.49:423-429.

Saheed, S.M. and Hussain, M.S. 1992. Wetland soils of Bangladesh. In: J.M. Kimble (1992); characterization, classification and utilization of Wet soils. USDA, Soil conservation service. National soil survey centre. Lincoln, NE. P. 220 -229.

Nwdialo, B.E. and Lietzke, D.A. 1989. Mineralogy and weathering of soils in the Tnnessee Copper basin. Soil Sci.147 : 162-173

Uddin, M.J. 2002. The Agricultural potentiality of wetlands: A case study of the Chalan beel Areas of Bangladesh. Dhaka Univ. J. Biol. Sci.11(2):139-145.

White, J.L. 1985. Summary of results of mineralogical study of clay fractions of Bangladesh soils. In : Proceedings of the workshop on soil mineralogy. BARC, Dhaka, Bangladesh. 